\title{
Perbedaan Efikasi Diri Berdasarkan Tipe Pola Asuh Orangtua pada Remaja Tengah di Denpasar
}

\author{
A.A. Mas Diah Widiyanti dan Adijanti Marheni \\ Program Studi Psikologi, Fakultas Kedokteran, Universitas Udayana \\ diahwidiyanti@gmail.com
}

\begin{abstract}
Abstrak
Pola asuh orangtua merupakan segala bentuk dan proses interaksi yang terjadi antara orangtua dan anak yang merupakan pola pengasuhan tertentu dalam keluarga yang akan memberi pengaruh terhadap perkembangan kepribadian anak. Pembentukan efikasi diri pada remaja tidak terlepas dari pengaruh yang menyertainya, efikasi diri berkembang secara teratur. Awal dari pertumbuhan efikasi diri dipusatkan pada orang tua, kemudian dipengaruhi oleh saudara kandung, teman sebaya, dan orang dewasa lainnya. Dalam hal ini orang tua dan anggota keluarga memiliki peranan penting dalam pembentukan efikasi diri remaja. Pola asuh orang tua dan interaksi yang baik dengan anggota keluarga merupakan faktor pendukung untuk membentuk efikasi diri yang positif pada remaja. Dinamika pola asuh yang berbeda akan membentuk efikasi diri yang berbeda pula.

Penelitian ini adalah penelitian kuantitatif komparasi. Subjek penelitian ini adalah remaja tengah di Denpasar sebanyak 380 orang dengan kriteria Siswa kelas X dan XI SMA Negeri di Denpasar. Metode pengambilan sampel dengan metode Area Probability Random Sampling. Metode pengambilan datanya dengan menggunakan Skala Pola Asuh yang telah diuji validitasnya, dengan reliabilitas 0,952 demikian juga Skala Efikasi Diri juga memiliki reliabilitas 0,962. Sebaran data yang diperoleh menunjukan data normal dan homogen. Metode analisis statistik dengan teknik komparasi One Way Anova. Didapatkan hasil F= 22,275; p= 0,000 dan analisis Post Hoc mendapatkan hasil yang menunjukkan bahwa Pola asuh Autoritatif dengan Otoriter memiliki signifikansi sebesar 0,000, pola asuh Autoritatif dengan Permisif sebesar 0,000 , pola asuh Permisif dengan Otoriter sebesar 0,163 . Artinya adanya perbedaan efikasi diri berdasarkan tipe pola asuh Autoritatif dengan Otoriter, perbedaan efikasi diri pola asuh Autoritatif dengan Permisif, dan tidak ada perbedaan efikasi diri pada pola asuh Permisif dengan Otoriter pada remaja tengah di Denpasar.
\end{abstract}

Kata kunci : Pola Asuh Orangtua, Efikasi Diri, Remaja Tengah

\begin{abstract}
Parenting style are all forms of interaction process between parent and child that will give effect to the personality development of children. The growth of self-efficacy in adolescents is evolve regularly. Beginning of the growth of self-efficacy focused on the elderly, then influenced by siblings, peers, and other adults. In this case the parents and family members have an important role in the formation of adolescent self-efficacy. Patterns of parenting and good interaction with family members is a contributing factor to form a positive self-efficacy in adolescents. Different dynamics of parenting style will also form a different self efficacy in adolescents. The aim of this research is to investigate the difference of self-efficacy based on parenting style of middle adolescents in Denpasar.

This research is quantitative comparison. The subjects were middle adolescents in Denpasar as many as 380 people to the criteria of Grade X and XI Senior High School in Denpasar. The sample were selected using Area Probability Random Sampling Method. Method of data collection using the Parenting Scale has tested its validity, the reliability of 0.952 as well as Self-Efficacy Scale also has reliability 0.962 . Distribution of the data obtained indicates normal data and homogeneous. Statistical analysis methods with techniques of comparative One Way Anova. Results obtained $\mathrm{F}=22.275, \mathrm{p}=0.000$ and analysis of Post Hoc get results indicate that the authoritative parenting has a significance of 0.000 Authoritarian, authoritative parenting with 0,000 Permissive, Authoritarian parenting Permissive amounted to 0.163 . It means that the difference in self-efficacy based on the type of authoritative parenting with authoritarian, self-efficacy differences with Permissive parenting authoritative, and there is no difference in self-efficacy on the Authoritarian Permissive parenting adolescents in the middle of Denpasar.
\end{abstract}

Keywords : Parenting Style, Self-Efficacy, Middle Adolescents 


\section{LATAR BELAKANG}

Masa remaja merupakan masa yang penting dalam tahap transisi seseorang (Bandura dalam Mahardikawati, 2012). Pada tahapan ini, remaja dihadapkan pada berbagai perubahan yang terjadi dalam fase perkembangannya. Ada tiga aspek perkembangan pada masa remaja yang dikemukakan Papalia dan Olds (2001) yaitu : (1) perkembangan fisik; (2) kognitif; (3) kepribadian dan sosial. Pada masa ini banyak tuntutan dan tekanan yang ditujukan pada remaja, misalnya mereka diharapkan untuk tidak lagi bertingkah seperti anak-anak, mereka harus lebih mandiri, dan bertanggung jawab (Jahja, 2011).

Menurut Jahja (2011), salah satu perubahan yang terjadi selama masa remaja yaitu kebanyakan remaja bersikap ambivalen dalam menghadapi perubahan yang terjadi. Di satu sisi mereka menginginkan kebebasan, tetapi di sisi lain mereka takut akan tanggung jawab yang menyertai kebebasan ini, serta meragukan kemampuan mereka sendiri untuk memikul tanggung jawab ini. Perubahan-perubahan yang terjadi pada masa remaja ini membuat mereka merasa tidak yakin akan diri dan kemampuan mereka sendiri (Jahja, 2011). Padahal, menurut William Kay (dalam Jahja, 2011), salah satu tugas perkembangan remaja yaitu remaja mampu menerima dirinya sendiri dan memiliki kepercayaan terhadap kemampuannya sendiri. Pada sebagian remaja, bukan merupakan hal yang mudah untuk menjalani perubahan tersebut, sehingga pada masa ini remaja harus memiliki keyakinan yang kuat bahwa mereka mampu melewati dan menjalankan perubahan yang ada. Keyakinan tersebut disebut dengan efikasi diri. Bandura (dalam Feist \& Feist, 2009) mendefinisikan efikasi diri sebagai keyakinan seseorang terhadap kemampuannya untuk dapat mengukur keberfungsiannya serta hal-hal yang terjadi di lingkungannya.

Pada sebagian remaja, bukan merupakan hal yang mudah untuk menjalani perubahan tersebut, sehingga pada masa ini remaja harus memiliki keyakinan yang kuat bahwa mereka mampu melewati dan menjalankan perubahan yang ada. Keyakinan tersebut disebut dengan efikasi diri. Dalam teori sosial kognitif, Bandura (dalam Mahardikawati, 2012) menyatakan bahwa efikasi diri ini membantu seseorang dalam menentukan pilihan, usaha mereka untuk maju, kegigihan dan ketekunan yang mereka tunjukkan dalam menghadapi kesulitan, dan derajat kecemasan atau ketenangan yang mereka alami saat mereka mempertahankan tugas-tugas yang mencakupi kehidupan mereka. Menurut Bandura (dalam Feist \& Feist, 2009), orang-orang yang percaya bahwa dirinya memiliki potensi untuk merubah hal-hal yang ada di lingkungannya akan bertindak aktif serta lebih sukses dibandingkan dengan orang-orang yang memiliki efikasi diri yang rendah. Remaja yang memiliki efikasi diri yang positif ialah remaja yang yakin bahwa dirinya mampu menjalankan tugas perkembangan sebagai seorang remaja dan cenderung mampu melewati masa remaja ini dengan baik. Sebaliknya remaja yang memiliki efikasi diri yang negatif akan cenderung mengalami kebingungan dan bermasalah pada masa remaja ini.

Namun pada kenyataannya terdapat banyak fenomena dikalangan remaja yang menunjukkan adanya gejala rendahnya efikasi diri, salah satunya yaitu dalam bidang pendidikan. hasil wawancara awal yang dilakukan oleh peneliti terhadap seorang remaja usia pertengahan yang memiliki IQ superior namun tidak menunjukkan prestasi belajar sesuai dengan kemampuan yang dimilikinya. Hal tersebut dikarenakan remaja memiliki keyakinan yang rendah untuk dapat masuk ke kelas akselerasi yang tersedia di sekolahnya, padahal ia memiliki kriteria IQ yang tinggi sebagai syarat untuk masuk ke dalam kelas tersebut. Keyakinan diri yang rendah pada remaja tersebut dikarenakan oleh faktor keluarga sebagai faktor utama penyebabnya, adanya penerapan pola asuh otoriter yang dilakukan oleh Ayahnya.

Efikasi diri sangat mempengaruhi mekanisme perilaku manusia. Jika orang yakin mempunyai kemampuan untuk menghasilkan sesuatu yang diinginkan maka individu akan berusaha untuk mencapainya. Akan tetapi jika individu tidak mempunyai keyakinan untuk menghasilkan sesuatu yang diinginkan maka ia tidak akan berusaha untuk mewujudkannya (Bandura dalam Susilowati, 2009). Efikasi diri penting dimiliki oleh kalangan remaja agar mampu terus menghadapi segala perubahan yang terjadi. Dengan memiliki efikasi diri yang tinggi, maka remaja juga memiliki keyakinan yang kuat untuk selalu dapat menghadapi segala perubahan serta tanggung jawab yang mereka miliki dalam menghadapi masa-masa perkembangan dalam kehidupannya.

Pembentukan efikasi diri pada remaja tidak terlepas dari pengaruh yang menyertainya. Bandura (dalam Anwar, 2009) menyatakan bahwa efikasi diri berkembang secara teratur. Awal dari pertumbuhan efikasi diri dipusatkan pada orang tua, kemudian dipengaruhi oleh saudara kandung, teman sebaya, dan orang dewasa lainnya (Bandura dalam Mahardikawati, 2012). Keluarga merupakan lembaga sosialisasi yang pertama dan utama bagi seorang anak Pengasuhan anak dipercaya memiliki dampak terhadap perkembangan individu (Lestari, 2012). Orang tua sebagai orang dewasa yang memberikan pengarahan kepada anaknya mengenai hal-hal yang harus dilakukan untuk dapat bertahan hidup di luar keluarganya (Wirawan, 2012).

Orangtua memiliki cara yang berbeda-beda dalam mendidik anaknya, salah satunya dengan menggunakan penerapan pola asuh yang berbeda. Pola asuh orang tua merupakan segala bentuk dan proses interaksi yang terjadi antara orang tua dan anak yang merupakan pola pengasuhan tertentu dalam keluarga yang akan memberi pengaruh terhadap perkembangan kepribadian anak (Baumrind dalam 
Irmawati, 2002). Pola asuh orangtua dan interaksi yang baik dengan anggota keluarga merupakan salah satu faktor pendukung untuk pembentukan efikasi diri yang positif pada remaja. Pengajaran yang diberikan orangtua akan membentuk kemandirian yang baik pada remaja. Kemandirian akan membentuk efikasi diri yang baik pula pada diri remaja (Wirawan, 2012). Menurut Soetjiningsih (2004), setiap orangtua memiliki cara pengasuhan yang berbeda serta akan menghasilkan kemandirian yang berbeda pula pada tiap anak. Oleh karena itu, maka dinamika pola asuh yang berbeda akan membentuk efikasi diri yang berbeda antara individu satu dengan yang lainnya.

\section{METODE}

\section{Variabel dan definisi operasional}

Variabel penelitian secara teoritis didefinisikan sebagai atribut seseorang atau objek yang mempunyai "variasi" antara satu orang dengan yang lain dan ditetapkan oleh peneliti utnuk dipelajari sehingga diperoleh informasi tentang hal tersebut, kemudian dapat ditarik kesimpulannya (Sugiyono, 2012). Pada penelitian kali ini, peneliti menetapkan dua jenis variabel yaitu variabel bebas dan variabel tergantung. Variabel bebas dalam penelitian ini adalah pola asuh orangtua dan variabel tergantung dalam penelitian ini adalah efikasi diri.

Definisi dari variable bebas, pola asuh orangtua adalah proses yang mempengaruhi seseorang, dimana orangtua menanamkan nilai-nilai yang dipercayai kepada anak dalam bentuk interaksi meliputi kepemimpinan, pengasuhan, mendidik, membimbing, dan melindungi anak yang akan memberi pengaruh terhadap perkembangan kepribadian anak. Pola Asuh Orangtua terbagi menjadi 3 tipe yaitu Pola Asuh Autoritatif, Otoriter, dan Permisif (Baumrind dalam Papalia, 2009). Variabel pola asuh orangtua ini diukur dengan menggunakan skala pola asuh orangtua yang telah dimodifikasi oleh peneliti agar sesuai dengan tujuan penelitian dengan model skala likert. Skala likert dalam kuesioner pola asuh orangtua ini terdiri dari 5 kategori jawaban yaitu, Sangat Setuju (SS), Setuju (S), Ragu-ragu (R), Tidak Setuju (TS), dan Sangat Tidak Setuju (STS). Hasil ukur dari variabel ini dilihat berdasarkan skor tiap item dengan menggolongkan tipe-tipe pola asuh berdasarkan skor dengan menggunakan kategorisasi bukan-jenjang (Nominal). Kategorisasi dari masing-masing tipe pola asuh ditentukan dengan cara menghitung Z-score dari skor total masing-masing tipe pola asuh.

Definisi dari variable tergantung, efikasi diri adalah keyakinan atau kepercayaan individu terhadap kemampuan yang dimilikinya dalam melaksanakan dan menyelesaikan tugas yang dihadapinya sehingga dapat mengatasi rintangan dan mencapai tujuan yang diharapkannya. Efikasi diri terdiri dari 3 aspek yaitu Level, Generality, dan Strength (Bandura dalam Anwar, 2009). Variabel efikasi diri diukur dengan menggunakan skala efikasi diri yang telah dimodifikasi oleh peneliti agar sesuai dengan tujuan penelitian dengan model skala likert. Skala likert dalam kuesioner pola asuh orangtua ini terdiri dari 5 kategori jawaban yaitu, Sangat Setuju (SS), Setuju (S), Ragu-ragu (R), Tidak Setuju (TS), dan Sangat Tidak Setuju (STS). Hasil ukur dari variabel ini dilihat berdasarkan skor tiap aitem kemudian di total, total skor menunjukan skor tingkat efikasi diri (jenis data yang dihasilkan data interval). Semakin tinggi skor menunjukan tingkat efikasi diri remaja semakin baik.

Responden

Populasi adalah wilayah generalisasi yang terdiri dari obyek atau subyek yang mempunyai kualitas dan karakteristik tertentu yang ditetapkan oleh peneliti untuk dipelajari dan kemudian ditarik kesimpulannya (Sugiyono, 2012). Pada penelitian ini peneliti mencari populasi remaja usia pertengahan yang ada di Denpasar. Sampel adalah bagian dari jumlah dan karakteristik yang dimiliki oleh populasi (Sugiyono, 2012). Sampel penelitian ini diambil dari populasi yang memenuhi kriteria inklusi.

1. Kriteria Inklusi Subjek Penelitian

a. Remaja usia pertengahan yang masih memiliki orang tua lengkap dan tinggal bersama orang tuanya.

b. Remaja dengan rentang usia 15-18 tahun

c. Subyek tinggal di Denpasar

d. Subjek tersebut bersedia menjadi responden

2. Kriteria Eksklusi Subjek Penelitian

a. Remaja usia pertengahan yang tinggal sendiri dan tidak tinggal dengan orangtuanya

b. Subyek tidak menetap di Denpasar

c. Subjek tersebut tidak bersedia mengisi alat ukur atau tidak bersedia menjadi responden

Teknik sampling merupakan teknik pengambilan sampel, untuk menentukan sampel dalam penelitian terdapat berbagai teknik sampling yang digunakan. Teknik Sampling pada dasarnya dapat dikelompokkan menjadi dua yaitu Probability Sampling dan Nonprobability Sampling (Sugiyono, 2012). Penelitian ini menggunakan teknik Area Probability Random Sampling dimana dalam teknik ini suatu daerah besar dibagi-bagi ke dalam daerah-daerah kecil, dan daerah kecil ini pada gilirannya dibagi-bai lagi menjadi daerah-daerah yang lebih kecil lagi (Hadi, 1988).

Hal ini dilakukan oleh peneliti agar mempermudah proses pengambilan data dan untuk mengambil jumlah responden yang akan digunakan sesuai dengan rumus Slovin dengan mengetahui mengetahui jumlah populasi remaja usia pertengahan di Denpasar. Cara seperti ini bisa untuk dilakukan apabila sulit menentukan atau menemukan kerangka sampel meski dapat juga dilakukan pada populasi yang kerangka sampel sudah ada. Pada tahap awal, peneliti mendatangi Dinas Pendidikan yang terdapat di Denpasar. Setelah memperoleh 
informasi mengenai jumlah SMA Negeri yang terdapat di Denpasar, peneliti menetukan sampel daerah. Dimana pada penelitian ini Kota Denpasar yang memiliki 4 Kecamatan yaitu : Denpasar Utara, Denpasar Timur, Denpasar Selatan, Denpasar Barat. Pada masing-masing kecamatan diambil 1sekolah SMA Negeri yaitu SMAN 1 Denpasar, SMAN 2 Denpasar, SMAN 3 Denpasar, dan SMAN 4 Denpasar. Kemudian menentukan orang-orang yang ada pada daerah itu secara sampling juga sesuai dengan kriteria inklusi untuk digunakan sebagai subjek penelitian. Pada penelitian ini, populasi dari sampel penelitian berjumlah 6.898 orang yang berasal dari 4 kecamatan di Kota Denpasar. Jumlah minimal sampel yang harus diambil agar penelitian ini dapat digeneralisasikan dihitung dengan menggunakan rumus dari Slovin (Darmadi, 2012) diperoleh jumlah minimal sampel dalam penelitian ini agar dapat digeneralisasikan adalah 378 orang. Dalam penelitian yang dilakukan peneliti mengambil jumlah sampel melebihi dari minimal pengambilan sampel yaitu sejumlah 380 orang yang memiliki kategori sesuai dengan yang telah ditentukan sebelumnya. Hal ini dikarenakan semakin banyak jumlah subyek yang digunakan akan semakin meningkatkan generalisasi penelitian (Sugiyono, 2009).

\section{Tempat Penelitian}

Responden dalam penelitian ini adalah remaja tengah yang tinggal di Denpasar, memiliki orangtua yang lengkap dan tinggal bersama orangtuanya. Pada tahap awal, peneliti mendatangi Dinas Pendidikan yang terdapat di Denpasar. Setelah memperoleh informasi mengenai jumlah SMA Negeri yang terdapat di Denpasar, peneliti menetukan sampel daerah. Dimana pada penelitian ini Kota Denpasar yang memiliki 4 Kecamatan yaitu : Denpasar Utara, Denpasar Timur, Denpasar Selatan, Denpasar Barat. Pada masing-masing kecamatan diambil satu sekolah SMA Negeri yaitu SMAN 1 Denpasar, SMAN 2 Denpasar, SMAN 3 Denpasar, dan SMAN 4 Denpasar.

\section{Alat Ukur}

Alat ukur yang digunakan dalam penelitian ini adalah dengan menggunakan kuesioner. Variabel bebas pada penelitian ini adalah pola asuh orangtua, yang dibagi menjadi tiga tipe yaitu pola asuh Autoritatif, Otoriter, dan Permisif (Baumrind dalam Papalia, 2009). Kuesioner pola asuh orangtua dalam hal ini bertujuan untuk menentukan tipe pola asuh orangtua yang diterapkan pada masing-masing remaja dimana terdapat 48 aitem pertanyaan favorable dan unfavorable. Skala pengukuran yang digunakan pada kuesioner pola asuh orangtua adalah skala likert dengan pilihan 5 jawaban yaitu, Sangat Setuju (SS), Setuju (S), Ragu-ragu (R), Tidak setuju (TS), dan Sangat Tidak Setuju (STS). Hasil ukur dari variabel ini dilihat berdasarkan skor tiap item dengan menggolongkan tipe-tipe pola asuh berdasarkan skor dengan menggunakan kategorisasi bukan-jenjang (Nominal). Kategorisasi dari masing-masing tipe pola asuh ditentukan dengan cara menghitung Z-score dari skor total masing-masing tipe pola asuh.

Variabel tergantung pada penelitian ini adalah efikasi diri. Efikasi diri terdiri dari 3 aspek yaitu Level, Generality, dan Strength (Bandura dalam Anwar, 2009). Variabel efikasi diri diukur dengan menggunakan skala efikasi diri yang telah dimodifikasi oleh peneliti agar sesuai dengan tujuan penelitian dengan model skala likert. Skala likert dalam kuesioner pola asuh orangtua ini terdiri dari 5 kategori jawaban yaitu, Sangat Setuju (SS), Setuju (S), Ragu-ragu (R), Tidak Setuju (TS), dan Sangat Tidak Setuju (STS). Hasil ukur dari variabel ini dilihat berdasarkan skor tiap aitem kemudian di total, total skor menunjukan skor tingkat efikasi diri (jenis data yang dihasilkan data interval). Semakin tinggi skor menunjukan tingkat efikasi diri remaja semakin baik.

Sebelum alat ukur digunakan dalam melakukan penelitian dilaksanakan uji coba terlebih dahulu terhadap kuesioner. Uji coba dilakukan kepada 70 responden siswa SMA Negeri di Denpasar. Pada uji coba ini menyatakan bahwa validitas kuesioner pola asuh orangtua bergerak dari 0,115 - 0,754. Validitas aitem pola asuh orangtua berada di bawah nilai 0,20 dinyatakan tidak valid, sehingga terdapat 12 aitem dari 60 aitem dalam kuesioner pola asuh orangtua yang harus digugurkan sehinga total aitem yang valid adalah 48 aitem. Setelah 12 aitem digugurkan, validitas mengalami perubahan sehingga pergerakan validitas aitem adalah dari 0,210 - 0,766 Validitas aitem pola asuh orangtua berada di atas 0,20 sehingga seluruh aitem dalam kuesioner dinyatakan valid (Nurgiyantoro, Gunawan, \& Marzuki, 2009). Reliabilitas kuesioner pola asuh orangtua adalah 0,952 yang berada di atas nilai maksimum 0,6 sehingga kuesioner dapat dinyatakan reliabel (Azwar, 2000).

Uji coba yang dilakukan pada kuesioner efikasi diri menyatakan bahwa validitas aitem berkisar pada angka 0,258 0,751 . Untuk meningkatkan validitas dari skala efikasi diri terdapat 3 aitem yang digugurkan dari 60 aitem yang terdapat dalam kuesioner efikasi diri. Setelah 3 aitem digugurkan, validitas mengalami perubahan sehingga pergerakan validitas aitem adalah dari 0,291 - 0,761. Validitas aitem pola asuh orangtua berada di atas 0,20 sehingga seluruh aitem dalam kuesioner dinyatakan valid (Nurgiyantoro, Gunawan, \& Marzuki, 2009). Reliabilitas kuesioner pola asuh orangtua adalah 0,962 yang berada di atas nilai maksimum 0,6 sehingga kuesioner dapat dinyatakan reliabel (Azwar, 2000). 


\section{Metode Pengumpulan Data}

Pada tahap pengumpulan data ini peneliti menggunakan kuesioner dengan dua skala, yaitu skala pola asuh dan skala efikasi diri . Kuesioner 1 yang berisi tentang skala pola asuh (untuk mengetahui gambaran tipe pola asuh yang diterapkan oleh orang tua subjek). Kuesioner 2 tentang efikasi diri (untuk mengukur efikasi diri subjek). Pengumpulan data dilakukan dengan mengajukan surat permohonan ijin penelitian pada tiap SMA Negeri di Denpasar yang menjadi sasaran penelitian. Setelah itu, responden akan mengisi kuesioner yang akan dibagikan oleh peneliti. Skala yang digunakan dalam penelitian ini berupa skala likert. Angket tersebut akan dibagikan kepada subjek selaku responden untuk diisi, sehingga akan menghasilkan atau memberikan respon jawaban tertulis terhadap sejumlah pernyataan yang telah disusun sebelumnya. Ada dua jenis angket yang akan diberikan oleh responden yaitu : skala pola asuh orangtua dan skala efikasi diri yang diisi langsung oleh subjek. Kedua alat ukur tersebut disusun berdasarkan konsepkonsep yang terdapat pada teori dan telah dimodifikasi oleh peneliti agar sesuai dengan tujuan penelitian. Skala yang digunakan pada kuesioner pola asuh dan efikasi diri adalah skala likert dengan 5 (lima) kategori pilihan jawaban. Selain itu, kuesioner ini juga terdiri dari item positif (favorable) dan item negatif (unfavorable).

\section{Teknik Analisis Data}

Analisis data yang digunakan dalam penelitian ini adalah analisis statistik karena statistik bekerja dalam angkaangka, bersifat obyektif dan universal, dalam arti dapat digunakan hampir pada semua bidang penelitian (Hadi, 1995). Metode penelitian merupakan salah satu unsur penting dalam penelitian ilmiah. Ketepatan dalam menggunakan metode penelitian merupakan dasar dalam memecahkan masalah penelitian. Penelitian ini adalah penelitian komparasi dengan pendekatan kuantitatif. Penelitian komparasi adalah penelitian yang bertujuan untuk menentukan ada tidaknya perbedaan, serta melihat perbedaan atau perbandingan antara dua variabel atau lebih (Sumanto, 1990). Desain yang digunakan dalam penelitian ini adalah kuantitatif komparasi menggunakan perhitungan Metode One Way Anova dengan program analisis statistik komputer yaitu Statistical Package forSocial Science (SPSS) versi 17 for windows. Metode Anova (Analysis of variance) adalah tergolong analisis komparatif lebih dari dua atau lebih dari dua rata-rata. Tujuan pada metode ini untuk membandingkan lebih dari dua rata-rata. Gunanya untuk menguji kemampuan generalisasi artinya data sampel dianggap dapat mewakili populasi (Riduwan \& Sunarto, 2009). Metode penilitian ini diharapkan dapat menemukan perbedaan fungsional dan perbedaan antara variabel-variabel yang diteliti yaitu pola asuh orang tua dengan efikasi diri siswa. Adapun tujuan peneliti menggunakan metode one way anova yaitu ingin melihat besar kontribusi IV ( pola asuh orangtua) terhadap DV (efikasi diri) serta pada metode one way anova terdapat post hoc test yang berfungsi untuk mengetahui hasil perbandingan antara masing-masing tipe pola asuh orang tua terhadap efikasi diri sehingga nantinya akan memperkaya data ketika membahas hasil penelitian.

\section{HASIL PENELITIAN}

Penelitian ini merupakan jenis penelitian komparatif yang termasuk dalam penelitian noneksperimen. Analisis yang digunakan pada penelitian ini adalah metode One Way Anova. Dalam melakukan analisis menggunakan metode One Way Anova, terdapat dua syarat yang harus dipenuhi sebelumnya, yaitu dilakukannya uji asumsi berupa uji normalitas dan uji homogenitas terhadap data yang diperoleh dalam suatu penelitian. Uji asumsi memiliki fungsi untuk memastikan dipenuhinya syarat untuk melakukan uji dari data yang diperoleh dalam penelitian (Sulaeman, 2010). Uji homogenitas digunakan untuk mengetahui apakah varians skor yang diukur pada setiap kelompok yang diuji homogeny atau tidak. Uji normalitas distribusi data dan uji homogenitas dilakukan dengan alat bantu perangkat lunak SPSS 17.0 for windows.

\section{Tabel 1. Hasil Uji Normalitas}

\begin{tabular}{|c|c|c|}
\hline No & Keterangan & $\begin{array}{c}\text { Nilai Efikasi } \\
\text { Diri }\end{array}$ \\
\hline \multirow{4}{*}{1} & Nilai Kolmogorov-Smirnov Z & 1,007 \\
& Nilai Sig. & 0,263 \\
\hline
\end{tabular}

Hasil uji normalitas diatas dengan sampel 380 orang, diketahui bahwa sebaran data variabel efikasi diri memiliki nilai signifikansi dengan probabilitas (p) 0,263 atau memiliki probabilitas diatas $0,05(\mathrm{p}>0,05)$. Hal tersebut menunjukan bahwa data berdistribusi normal.

Tabel 2. Hasil Uji Homogenitas

\begin{tabular}{|c|c|c|}
\hline No & Keterangan & Nilai \\
\hline \multirow{4}{*}{1} & Uji Homogenitas & \\
& Levene's Test & \\
& Nilai F & 1,424 \\
& Nilai Sig. & 0,235 \\
\hline
\end{tabular}

Berdasarkan tabel hasil uji homogenitas diatas, diketahui bahwa varians pada setiap kelompok memiliki nilai homogenitas pada Levene Statistic sebesar 1,424 dengan nilai signifikansi dengan probabilitas (p) 0,235 atau memiliki probabilitas di atas 0,05 ( $\mathrm{p}>0,05)$. Mengacu kepada pedoman penentuan homogenitas, nilai probabilitas (p) 0,235 tersebut 
menunjukkan bahwa varians skor variabel yang diukur pada setiap kelompok yang diuji dalam penelitian ini adalah bersifat homogen. Sehingga data ini dapat dianalisis dengan menggunakan analisis parametrik (one way anova) dengan menggunakan alat bantu perangkat lunak SPSS 17.0 for windows. Variabel yang akan di uji adalah variabel pola asuh dengan efikasi diri.

Peneliti membedakan kategori dari masing-masing variabel dengan menggunakan rumus rentangan berdasarkan standar deviasi dan mean empiris dilihat dari kurva normal (Azwar, 2000). Kategorisasi yang dilakukan oleh peneliti terbagi kedalam 3 kategori, yaitu kategori rendah, sedang, tinggi pada kategori efikasi diri.

Berdasarkan rumus pengkategorian skor dari Azwar (2000), peneliti kemudian mengkategorikan variabel efikasi diri ke dalam tiga kategori. Pengkategorian skor efikasi diri dan persentasenya akan dicantumkan dalam tabel dibawah ini

Tabel 3. Hasil kategorisasi skor pada kuesioner efikasi diri

\begin{tabular}{|c|c|c|c|}
\hline Skor & Kategorisasi & Jumlah & Persentase \\
\hline $\mathrm{X}<133$ & Rendah & 21 & $5,5 \%$ \\
\hline $\begin{array}{c}133 \leq \mathrm{X}< \\
209\end{array}$ & Sedang & 211 & $55,5 \%$ \\
\hline $209 \leq \mathrm{X}$ & Tinggi & 148 & $38,9 \%$ \\
\hline TOTAL & & $\mathbf{3 8 0}$ & $\mathbf{1 0 0} \%$ \\
\hline
\end{tabular}

Dilihat pada tabel diatas merupakan hasil kategorisasi skor efikasi diri pada kuesioner efikasi diri. Terdapat 148 siswa yang memiliki efikasi diri tinggi dengan persentase $38,9 \%$. Siswa yang memiliki efikasi diri sedang sebanyak 211 siswa dengan persentase 55,5\%. Siswa dengan efikasi diri rendah terdapat 21 siswa dengan persentase 5,5\%. Dalam hal ini siswa dengan efikasi diri sedang lebih banyak dibandingkan siswa dengan efikasi diri rendah dan tinggi.

Tabel 4. Hasil pengkategorian skor efikasi diri berdasarkan tipe pola asuh

\begin{tabular}{|c|c|c|c|c|c|c|c|}
\hline & & & & Kat & egori efika & ısi diri & \\
\hline & & & & rendah & sedang & tinggi & Total \\
\hline ktpolaasuh & Autoritati & Count & & 1 & 35 & 70 & 106 \\
\hline & & $\begin{array}{l}\% \\
\text { ktpolaasuh }\end{array}$ & within & $.9 \%$ & $33.0 \%$ & $66.0 \%$ & $100.0 \%$ \\
\hline & Otoriter & Count & & 11 & 33 & 11 & 55 \\
\hline & & $\begin{array}{l}\% \\
\text { ktpolaasuh }\end{array}$ & within & $20 \%$ & $60 \%$ & $20 \%$ & $100.0 \%$ \\
\hline & Permisif & Count & & 5 & 42 & 12 & 59 \\
\hline & & $\begin{array}{l}\% \\
\text { ktpolaasuh }\end{array}$ & within & $8.5 \%$ & $71.2 \%$ & $20.3 \%$ & $100.0 \%$ \\
\hline
\end{tabular}

Pada tabel 4 dapat kita lihat pengkategorian efikasi diri tinggi, efikasi diri sedang dan efikasi diri rendah berdasarkan tiga tipe pola asuh. Orangtua yang mengasuh remajanya dengan tipe Autoritatif kebanyakan remajanya memiliki tingkat efikasi diri tinggi dan sedang. Serta hanya 1 orang yang memiliki efikasi diri rendah. Berbeda dengan pola asuh Otoriter, meskipun kebanyakan remaja memiliki tingkat efikasi diri sedang tetapi masih terdapat sebagian remajanya yang memiliki tingkat efikasi diri rendah sebanyak $11 \%$. Selain itu orangtua yang mengasuh remajanya dengan tipe pola asuh Permisif kebanyakan remajanya memiliki efikasi diri sedang lebih banyak dibandingkan dengan pola asuh Autoritatif dan pola asuh Otoriter dengan persentase sebanyak $42 \%$.

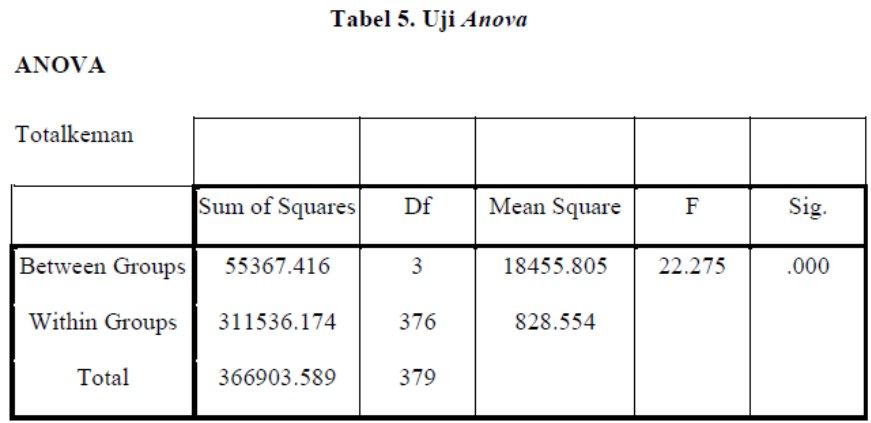

Tabel ANOVA berguna untuk menguji perbedaan antara rata-rata jumlah error pada tipe pola asuh setelah data terbukti homogen melalui homogenity test. Berdasarkan tabel diatas menunjukkan bahwa Uji One Way Anova nilai Sig. (2tailed) menunjukkan angka 0,000.

Dilihat pada hasil analisis data, nilai signifikansi yang diperoleh sebesar 0,000 dimana nilai tersebut lebih kecil dari taraf signifikansi $0,05(\mathrm{p}<0,05)$. Jadi dapat disimpulkan bahwa ada perbedaan yang signifikan antara ketiga tipe pola asuh terhadap efikasi diri. Setelah memperoleh hasil nilai signifikansi perbedaan antara tipe pola asuh, maka selanjutnya di uji dengan Post Hoc dari One Way Anova.

Uji Post Hoc berguna untuk mengetahui metode mana saja yang menunjukkan perbedaan rata-rata. Dari analisis ANOVA sebelumnya terlihat bahwa ada beda signifikan antara tipe pola asuh sehingga dilakukan uji analisis Post hoc utuk mengetahui tipe pola asuh mana saja yang menunjukan perbedaan yang signifikan. Hasil Post Hoc adalah sebagai berikut :

Tabel 6. Post Hoc Test (One Way Anova)

\begin{tabular}{|c|c|c|c|c|c|c|}
\hline \multirow{2}{*}{\multicolumn{2}{|c|}{$\begin{array}{l}\text { (I) } \\
\text { ktpolaasuh } \\
\text { ktpolaasuh }\end{array}$}} & \multirow{2}{*}{$\begin{array}{c}\text { Mean } \\
\text { Difference (I-J) }\end{array}$} & \multirow[b]{2}{*}{ Std. Error } & \multirow[b]{2}{*}{ Sig. } & \multicolumn{2}{|c|}{$95 \%$ Confidence Interval } \\
\hline & & & & & Lower Bound & Upper Bound \\
\hline \multirow[t]{2}{*}{ Autoritatif } & Otoriter & $35.229^{\circ}$ & 5.015 & .000 & 25.34 & 45.11 \\
\hline & Permisif & $27.317^{\circ}$ & 4.902 & .000 & 17.66 & 36.98 \\
\hline \multirow[t]{2}{*}{ Otoriter } & Autoritatif & $-35.229^{*}$ & 5.015 & .000 & -45.11 & -25.34 \\
\hline & Permisif & -7.911 & 5.656 & .163 & -19.06 & 3.24 \\
\hline \multirow[t]{2}{*}{ Permisif } & Autoritatif & $-27.317^{*}$ & 4.902 & .000 & -36.98 & -17.66 \\
\hline & Otoriter & 7.911 & 5.656 & .163 & -3.24 & 19.06 \\
\hline
\end{tabular}

Untuk mengetahui tipe pola asuh mana saja yang menunjukkan perbedaan efikasi diri dengan signifikan maka 
dapat dilihat pada tanda bintang (*) yang menunjukkan adanya perbedaan mean (efikasi diri) yang signifikan berdasarkan tipe pola asuh orangtua dan dengan melihat nilai signifikansi $<0,05$. Dari tabel di atas, terlihat bahwa terdapat perbedaan efikasi diri pada pola asuh autoritatif dengan pola asuh otoriter, dengan signifikansi 0,000. Pada tipe pola asuh autoritatif dengan pola asuh permisif juga memiliki perbedaan efikasi diri dengan nilai signifikansi 0,000. Pada tipe pola asuh permisif tidak memiliki perbedaan efikasi diri dengan pola asuh otoriter dengan nilai signifikansi 0,163.

Tabel 7. Tabel Post Hoc Test (One Way Anova)

\begin{tabular}{|c|c|c|c|c|c|c|}
\hline \multirow{2}{*}{$\begin{array}{c}\text { (I) } \\
\text { ktpolaasuh }\end{array}$} & \multirow{2}{*}{$\begin{array}{c}\text { (J) } \\
\text { ktpolaasuh }\end{array}$} & \multirow{2}{*}{$\begin{array}{c}\text { Mean } \\
\text { Difference } \\
(\mathrm{I}-\mathrm{J})\end{array}$} & \multirow[t]{2}{*}{ Std. Error } & \multirow[t]{2}{*}{ Sig. } & \multicolumn{2}{|c|}{$95 \%$ Confidence Interval } \\
\hline & & & & & $\begin{array}{l}\text { Lower } \\
\text { Bound }\end{array}$ & $\begin{array}{l}\text { Upper } \\
\text { Bound }\end{array}$ \\
\hline \multirow{3}{*}{$\begin{array}{c}\text { Tipe } \\
\text { Campuran }\end{array}$} & Autoritatif & $-18.056^{*}$ & 3.605 & .000 & -25.14 & -10.97 \\
\hline & Otoriter & $17.172^{\circ}$ & 4.499 & .000 & 8.33 & 26.02 \\
\hline & Permisif & $9.261^{\circ}$ & 4.384 & .035 & .64 & 17.88 \\
\hline
\end{tabular}

Hasil penelitian terdapat tipe pola asuh campuran, tabel di atas dapat dilihat tentang perbedaan efikasi diri antara tipe pola asuh autoritatif, tipe pola asuh otoriter, tipe pola asuh permisif dan tipe pola asuh campuran. Pada tabel di atas terdapat tanda bintang $(*)$ yang menunjukkan adanya perbedaan mean (efikasi diri) yang berdasarkan tipe pola asuh orangtua dan dengan melihat nilai signifikansi $<0,05$. Dari tabel di atas terlihat bahwa terdapat perbedaan efikasi diri pada pola asuh tipe campuran dengan pola asuh autoritatif dengan nilai signifikan 0,000. Selain itu juga terdapat perbedaan efikasi diri yang signifikan antara pola asuh tipe campuran dengan pola asuh otoriter dengan nilai signifikan 0,000. Jika dilihat pada tabel mean antara pola asuh tipe campuran dengan pola asuh permisif juga menunjukkan adanya perbedaan yang signifikan dengan nilai 0,035 .

Dari hasil data yang telah diperoleh menunjukkan bahwa ada perbedaan efikasi diri antara ketiga tipe pola asuh orangtua. Jadi, dalam hal ini mendukung penerimaan Ha dan penolakan Ho, serta menjawab pembuktian hipotesis minor yang telah peneliti buat.

\section{PEMBAHASAN DAN KESIMPULAN}

Berdasarkan hasil analisis perbedaan dengan menggunakan one way anova, diketahui bahwa nilai signifikansi $\mathrm{p}$ adalah sebesar 0,000 lebih kecil dari taraf signifikansi $0,05(\mathrm{p}<0,05)$, sehingga dapat disimpulkan bahwa hipotesis alternatif (Ha) yang diajukan dalam penelitian diterima. Adapun hipotesis mayor yang diajukan dalam penelitian ini menunjukkan adanya perbedaan efikasi diri berdasarkan tipe pola asuh orangtua pada remaja tengah di Denpasar.

Adapun hipotesis minor yang diajukan oleh peneliti sesuai dengan hasil data yang diperoleh melalui uji post hoc dimana adanya perbedaan efikasi diri berdasarkan tipe pola asuh autoritatif dengan pola asuh otoriter dengan nilai signifikansi 0,000, adanya perbedaan efikasi diri berdasarkan tipe pola asuh autoritatif dengan permisif dengan nilai signifikansi 0,000. Tetapi tidak terdapat perbedaan efikasi diri berdasarkan tipe pola asuh otoriter dengan tipe pola asuh permisif dimana nilai signifikansinya 0,163 .

Diterimanya hipotesis mayor yang menunjukkan adanya perbedaan efikasi diri berdasarkan tipe pola asuh orangtua didukung dengan pernyataan Bandura (dalam Dwisty Anwar, 2009) dimana awal dari pertumbuhan efikasi diri dipusatkan pada orangtua kemudian dipengaruhi oleh saudara kandung, teman sebaya, dan orang dewasa lainnya. Dalam hal ini orangtua dan anggota keluarga memiliki peranan penting dalam pembentukan efikasi diri remaja. Pola asuh orangtua dan interaksi yang baik dengan anggota keluarga merupakan faktor pendukung untuk membentuk efikasi diri yang positif pada remaja (Bandura dalam Mahardikawati, 2011).

Hasil penelitian menunjukkan bahwa sebagian besar remaja tengah di Denpasar memiliki efikasi diri yang tergolong dalam kategori sedang, yaitu sebanyak 211 orang dengan persentase $55,5 \%$, hasil penelitian menunjukkan remaja tengah dengan efikasi diri rendah sebanyak 21 orang dengan persentase $5,5 \%$, dan remaja tengah dengan efikasi diri tinggi sebanyak 148 orang dengan persentase $38,9 \%$. Selain itu, hasil penelitian karakteristik tipe pola asuh orangtua menunjukkan bahwa orangtua yang menerapkan tipe pola asuh autoritatif sebanyak 106 orang dengan persentase 27,9\%, gambaran pola asuh orangtua yang menerapkan tipe pola asuh otoriter sebanyak 55 orang dengan persentase 14,5\%, dan gambaran pola asuh orangtua yang menerapakan pola asuh permisif sebanyak 59 orang dengan persentase $15,5 \%$.

Dalam hasil penelitian didapatkan pula pola asuh tipe campuran. Pola asuh tipe campuran ini merupakan pola asuh yang tidak dapat terklasifikasi ke dalam salah satu tipe pola asuh dimana orangtua menerapkan pola asuh ganda atau tidak mendominasi salah satu dari ketiga tipe pola asuh yang memang peneliti gunakan dalam penelitian ini. Hasil penelitian pada gambaran pola asuh orangtua mendapatkan orangtua yang menerapkan pola asuh tipe campuran sebanyak 160 orang dengan persentase $42,1 \%$. Kenyataannya orangtua tidak hanya menerapkan salah satu tipe pola asuh saja. Hal ini didukung dengan pendapat menurut Tedjasaputra (2008) bahwa ada kalanya setiap orangtua tidak mampu dalam menerapkan salah satu tipe pola asuh dengan sepenuhnya. Menurut Deater-Deckard (dalam Lestari,2012) adanya stres pengasuhan yang didefinisikan sebagai serangkaian proses yang membawa pada kondisi psikologis yang tidak disukai dan reaksi psikologis yang muncul dalam upaya beradaptasi dengan tuntutan peran sebagai orangtua. Gejala-gejala yang muncul misalnya menurunnya ekspresi kehangatan, meningkatnya metode pendisplinan yang keras, kurang 
konsistennya perilaku pengasuhan, dan menarik diri sepenuhnya dari peran pengasuhan.

Hasil pengkategorian efikasi diri tinggi, efikasi diri sedang, dan efikasi diri rendah dikaitkan dengan tipe-tipe pola asuh orangtua, dimana dalam gambaran tipe pola asuh autoritatif memiliki remaja dengan efikasi diri tinggi sebanyak 70 orang dengan persentase $66 \%$, efikasi diri sedang sebanyak 35 orang dengan persentase $33 \%$. Namun, tipe pola asuh autoritatif hanya terdapat satu orang dengan efikasi diri rendah. Berdasarkan pendekatan tipologi pola asuh yang dipelopori oleh Baumrind (dalam Lestari,2012) menganggap bahwa tipe pola asuh yang paling baik adalah tipe pola asuh autoritatif. Tipe pola asuh autoritatif dianggap sebagai gaya pengasuhan yang paling efektif menghasilkan akibat-akibat positif pada remaja. Pada tipe pola asuh autoritatif, orangtua mengarahkan perilaku remaja secara rasional, dengan memberikan penjelasan terhadap maksud dari aturan-aturan yang diberlakukan. Orangtua mendorong remaja untuk mematuhi aturan dengan kesadaran sendiri. Di sisi lain, orangtua bersikap tanggap terhadap kebutuhan dan pandangan remaja. Orangtua menghargai kedirian remaja dan kualitas kepribadian yang dimilikinya sebagai keunikan pribadi. Remaja dengan orangtua yang autoritatif akan cenderung periang, memiliki rasa tanggung jawab sosial, percaya diri, berorientasi prestasi dan lebih kooperatif.

Pada hasil penelitian terdapat gambaran pola asuh otoriter dengan efikasi diri rendah sebanyak 11 orang dengan persentase $20 \%$, efikasi diri sedang sebanyak 33 orang dengan persentase $60 \%$, dan efikasi diri tinggi sebanyak 11 orang dengan persentase 60\%. Baumrind (dalam Lestari, 2012) menyatakan gaya pengasuhan yang otoriter dilakukan oleh orangtua yang selalu berusaha membentuk, mengontrol, mengevaluasi perilaku dan tindakan remaja agar sesuai dengan aturan standar. Aturan tersebut biasanya bersifat mutlak yang dimotivasi oleh semangat teologis dan diberlakukan dengan otoritas yang tinggi. Kepatuhan remaja merupakan nilai yang diutamakan, dengan memberlakukan hukuman pada remaja apabila terjadi pelanggaran. Orangtua menganggap bahwa remaja merupakan tanggung jawabnya, sehingga segala yang dikehendaki orangtua yang diyakini demi kebaikan remaja merupakan kebenaran. Remaja-remaja kurang mendapat penjelasan yang rasional dan memadai atas segala aturan, kurang dihargai pendapatnya, dan orangtua kurang sensitif terhadap kebutuhan dan persepsi remaja. Remaja dengan orangtua yang otoriter akan cenderung merasa tidak puas, menarik diri, mudah curiga, serta tidak mampu mengambil keputusan atas perilakunya sendiri (Bandura dalam Papalia, 2009).

Hasil penelitian tentang gambaran pola asuh orangtua yang menerapkan tipe pola asuh permisif menghasilkan remaja dengan efikasi diri rendah sebanyak 5 orang dengan persentase $8,5 \%$, efikasi diri sedang sebanyak 42 orang dengan persentase $71,2 \%$, dan efikasi diri tinggi sebanyak 12 orang dengan persentase 20,3\%. Menurut Baumrind (dalam Lestari, 2012), menyatakan bahwa gaya pengasuhan yang permisif biasanya dilakukan oleh orangtua yang terlalu baik, cenderung memberi banyak kebebasan pada remaja-remaja dengan menerima dan memaklumi segala perilaku, tuntutan dan tidakan remaja, namun kurang menuntut sikap tanggung jawab dan keteraturan perilaku remaja. Orangtua yang demikian akan menyediakan dirinya sebagai sumber daya bagi pemenuhan segala kebutuhan remaja, membiarkan remaja untuk mengatur dirinya sendiri dan tidak terlalu mendorongnya untuk mematuhi standar eksternal. Remaja dengan orangtua permisif akan cenderung ragu-ragu dan merasa cemas dengan segala hal yang dilakukannya (Baumrind dalam Papalia, 2009). Mereka juga cenderung impulsif, agresif, kurang kontrol diri, kurang mandiri, dan kurang berorientasi pada prestasi (Baumrind dalam Lestari, 2012).

Melalui uji post hoc dapat dilihat perbedaan efikasi diri berdasarkan masing-masing tipe pola asuh orangtua. Terdapat perbedaan efikasi diri berdasarkan tipe pola asuh autoritatif dengan tipe pola asuh otoriter, perbedaan efikasi diri berdasarkan tipe pola asuh autoritatif dengan permisif. Tetapi tidak terdapat perbedaan efikasi diri berdasarkan tipe pola asuh otoriter dengan tipe pola asuh permisif. Dari kedua pola asuh tersebut dapat dilihat bahwa tipe pola asuh otoriter dan permisif dapat menghasilkan akibat-akibat negatif pada remaja, salah satu akibat negatif yang dihasilkan adalah rendahnya efikasi diri pada remaja. Menurut Baumrind (dalam Papalia, 2009) mengatakan bahwa remaja dengan pola asuh otoriter biasanya tidak mampu mengambil keputusan atas perilakunya sendiri. Remaja dengan tipe pola asuh permisif biasanya cenderung ragu-ragu dan merasa cemas dalam segala hal yang dilakukannya.

Hasil penelitian mendapatkan pola asuh tipe campuran, dimana orangtua menerapkan tipe pola asuh ini menghasilkan remaja dengan efikasi diri tinggi sebanyak 55 orang dengan persentase $34,4 \%$, efikasi diri sedang sebanyak 101 orang dengan persentase $63,1 \%$ dan efikasi diri rendah sebanyak 4 orang dengan persentase 2,5\%. Dilihat dari hasil penelitian bahwa pola asuh tipe campuran ini, remaja yang memiliki efikasi diri sedang lebih banyak dibandingkan tipe pola asuh autoritatif, pola asuh otoriter dan pola asuh permisif. Pola asuh autoritatif masih lebih baik jika dibandingkan dengan pola asuh otoriter, pola asuh permisif, dan pola asuh tipe campuran karena pada penelitian ini pola asuh autoritatif paling banyak menghasilkan remaja dengan efikasi diri tinggi yaitu sebanyak 70 orang dan hanya satu orang remaja yang memiliki efikasi diri rendah. Dari data yang telah didapatkan oleh peneliti, maka secara umum dapat disimpulkan bahwa tipe pola asuh yang paling baik yaitu tipe pola asuh autoritatif untuk menghasilkan remaja dengan efikasi diri yang baik. 
Berdasarkan hasil penelitian, maka sara-saran yang dapat diberikan untuk dapat meningkatkan efikasi diri khususnya bagi remaja tengah yaitu para orangtua agar lebih menerapkan pola asuh autoritatif, karena terbukti lebih efektif dalam mengembangkan efikasi diri pada remaja. Orangtua diharapkan menjadi sumber modelling yang baik bagi remaja, misalnya orangtua mampu melakukan pemecahan terhadap suatu permasalahan dengan baik atau memperoleh hasil yang maksimal di dalam suatu bidang. Orangtua sebaiknya memberi penghargaan atas segala pencapaian yang berhasil diraih oleh anaknya. Hal tersebut akan menumbuhkan keyakinan diri pada remaja dimana kelak ia mampu melakukan hal yang sama seperti yang telah dicapai oleh orangtuanya ; Saran bagi remaja sebaiknya remaja perlu menyadari pentingnya mengembangkan efikasi diri dalam kehidupan sehari-hari terutama apabila dihadapkan pada suatu permasalahan atau tantangan. Remaja sebaiknya mampu mengevaluasi seberapa jauh kemampuan yang ia miliki di dalam mengerjakan tugas-tugasnya serta menyadari apa saja yang menjadi kelebihan dan kekurangan yang ada di dalam dirinya ; serta saran bagi peneliti selanjutnya pada penelitian selanjutnya dengan topik yang sama agar lebih memperhatikan faktor-faktor lain yang mempengaruhi efikasi diri khususnya faktor teman sebaya. Peneliti selanjutnya sebaiknya mengkaji lebih lanjut mengenai kajian teori dari masing-masing tipe pola asuh orangtua, terutama mengenai pola asuh yang tidak terklasifikasi ke dalam ketiga tipe pola asuh yaitu pola asuh tipe campuran.

\section{DAFTAR PUSTAKA}

Anwar, A. I. (2009). Hubungan antara self-efficacy dengan kecemasan berbicara di depan umum pada mahasiswa fakultas psikologi universitas Sumatera Utara.

Arikunto, S. (1993). Seri manajemen sumber daya manusia psikologi industri. Bandung : Alumni.

Arikunto, Suharsimi (2006). Prosedur penelitian suatu pendekatan. Jakarta : PT Asdi Mahasatya.

Azwar, S. (2000). Penyusunan skala psikologi. Yogyakarta : Pustaka Pelajar.

Azwar, S. (2006). Reliabilitas dan validitas. Yogyakarta : Pustaka Pelajar.

Apriyani, H. (2009). Efektivitas pelatihan efikasi diri terhadap intensi masturbasi pada remaja.

Darmadi, H. (2011). Metode penelitian pendidikan. Bandung : Alfabeta.

Dewi, R. N. (2011). Hubungan antara efikasi diri dan kecemasan terhadap ujian nasional pada siswa kelas XII SMK Negeri Malang.

Dwitantyanov, A., Hidayanti, F., \& Sawitri, D. R. (2010). Pengaruh pelatihan berfikir positif pada efikasi diri akademik mahasiswa (Studi eksperimen pada mahasiswa fakultas psikologi Undip Semarang). Jurnal Psikologi Undip, 135144.
Dwitantyanov, A. (2013). Teori Perkembangan Emosional Remaja. Akses : $25 \quad$ September 2013, http://aswendo2dwitantyanov.wordpress.com/2013/01/19/te ori-perkembangan-emosional-remaja/

Feist, J \& Gregory J. Feist (2009). Theories of Personality : Seventh Edition. Singapore : McGraw-Hill.

Garliah, L., \& Nasution, F. K. (2005). Peran pola asuh orang tua dalam motivasi berprestasi.

Graziano, A.M., Raulin, M.L. 2000, Research Methods : A Process of Inquiry,

Allyn \& Bacon, M.A.,.

Gufroni, A. (2012). Perkembangan Psikososial Remaja. Akses : 25 September 2013, http://mudzaa.blogspot.com/2012/01/vbehaviorurldefaultvmlo.html

Guilford. J. P \& Benjamin Fruchter. (1956). Fundamental Statistic in psychology and educational. Tokyo: Mc-Graw-Hill.

Hadi, Sutrisno. (1988). Bimbingan menulis skripsi, tesis. Yogyakarta : Psikologi GAMA.

Hadi, Sutrisno. (1995). Statistik 1,2,3. Yogyakarta: Andi Offset.

Hurlock, E.B. (1999). Psikologi Perkembangan : Suatu Pendekatan Sepanjang Rentang Kehidupan (edisi ke-5). Jakarta: Erlangga.

Irmawati. (2002). Motivasi Berprestasi \& Pola Pengasuhan Pada Suku Bangsa Batak Toba \& Suku Bangsa Melayu (tesis). Jakarta: Fakultas Pasca UI

Jahja, Y. (2011). Psikologi perkembangan. Edisi Pertama. Jakarta : Penerbit Kencana.

Julianto, A. P. (2007). Hubungan pola asuh orang tua dengan tingkat kemandirian anak usia sekolah dasar di SDN Panjang Wetan 01 Pekalongan

Kerlinger, Fred. W. (2002). Asas-asas penelitian behavioral. Yogyakarta : Gadjah Mada University Press.

Lestari, S. (2012). Psikologi keluarga : Penanaman nilai dan penanganan konflik dalam keluarga. Edisi Pertama. Jakarta : Penerbit Kharisma Putra Utama.

Mahardikawati, D. (2012). Hubungan self-efficacy dengan prestasi belajar siswa.

Monks, F.J. (2002). Psikologi perkembangan : Pengantar dalam berbagai bagiannya. Yogyakarta : Gadjah Mada University Press.

Nurgiyantoro, B., Gunawan dan Marzuki. (2009). Statistik terapan untuk ilmu-ilmu sosial. Yogyakarta : Gadjah Mada University Press.

Papalia, DE, Olds SW, Feldman RD. (2001). Human Development. 8th ed. Boston:

McGraw-Hill.

Papalia, D. E., Olds, S. W., \& Feldman, R. D. (2009). Human development. New York: McGraw-Hill.

Rice, F.P. (1990). The adolescent development, relationship \& culture (6th ed.). Boston: Ally \& Bacon.

Riduwan \& H. Sunarto. (2009). Pengantar Statistika Untuk Penelitian : Pendidikan, Sosial, Komunikasi, Ekonomi, dan Bisnis. Bandung : Penerbit Alfabeta.

Sarwono, Sarlito W. (2012). Psikologi remaja. Jakarta : Penerbit Rajawali Pers.

Santrock (2003)

Setiadi. (2008). Konsep dan keperawatan keluarga. Yogyakarta: Graha Ilmu. 
Soetjiningsih. (2004).Tumbuh kembang remaja dan permasalahannya. Jakarta : Sagung Seto.

Sugiyono. (2009). Metode penelitian kuantitatif \& kualitatif dan R\&D. Bandung : CV. Alfabeta.

Sugiyono. (2010). Metode penelitian kuantitatif \& kualitatif dan R\&D. Bandung : CV. Alfabeta.

Sugiyono. (2012). Metode penelitian kuantitatif \& kualitatif dan R\&D. Bandung : CV. Alfabeta.

Sulaeman, W. (2011). Analisis regresi menggunakan SPSS, contoh kasus dan pembahasannya. Yogyakarta: Andi Offset.

Sumanto. (1990). Metodologi Penelitian Sosial dan Pendidikan. Yogyakarta : Andi Offset.

Suryabrata, S. (2000). Metode Penelitian. Jakarta : PT Raja Grafindo Persada.

Susilowati, A. (2009). Hubungan antara efikasi diri dengan prestasi belajar pada siswa SMA Negeri 8 Surakarta.

Tarsis, T. (2002). Hubungan pola asuh orang tua dengan agresivitas remaja. Jurnal pendidikan \& kebudayaan (37), 504-519.

Tedjasaputra, Mayke S. (2008). Pola asuh yang tepat. Akses : 26 Juni 2013, http://keluargasehat.wordpress.com/2008/04/10/

Wirawan, Septiadhi. (2012). Definisi efikasi diri. Akses : 28 Agustus 2013, http://id.scribd.com/doc/79008218/Efikasi-Diri

Yusuf, Syamsu. (2011). Psikologi Perkembangan Anak \& Remaja. Bandung : PT Remaja Rosdakarya. 